\title{
Yabancı Uyruklu Öğrencilerdeki Türkiye İmajı: Bursa Uludağ Üniversitesi Örneği*
}

Turkey's Image in International Students:

Bursa Uludag University Example

\section{H. Mustafa Bektaş ${ }^{* *}-$ K. Burcu Öngen Bilir ${ }^{* * *}$ Talip Alan ${ }^{\star \star \star * *}$}

\section{Öz}

Ülkemizde yakın dönem içerisinde yabancı uyruklu öğrenci sayısında önemli oranda artış olmuştur. Bu sayının büyük kısmı, eğitimlerini tamamladığında ülkemizden ayrılan geçici bir nüfus oluşumunu temsil etse de sürecin sadece kısa vadede değil uzun vadede de ülkemiz açısından birtakım sonuçları olabilmektedir. Ülkemizde belli bir süre kaldıktan sonra kendi ülkelerine veya başka ülkelere taşınan yabancı öğrencilerde oluşan Türkiye imajı uzun vadeli sonuçların en önemli etkenlerinden bir tanesidir. Bu bağlamda, ülkemize gelmeden önce ve geldikten sonra yabancı öğrencilerdeki Türkiye imajlarının nasıl olduğunu tespit etmek elzem olmaktadır. Mevcut çalışmanın

* Bu çalışma, Bursa Uludağ Üniversitesi Bilimsel Araştırma Projeleri Komisyonu tarafından desteklenen, "ÖAP(İ)-2018/7" numaralı "Yabanc1 Uyruklu Öğrencilerdeki Türkiye İmajı: Uludağ Üniversitesi Örneği" başlıklı geçen projeden türetilmiştir.

** This article has been derived from the project titled "Turkey's Image in International Students: Uludag University Example (ÖAP(İ)-2018/7)" that funded by Uludag University Scientific Research Projects Commission.

*** Dr.Öğr.Üyesi, Bursa Uludağ Üniversitesi, İktisadi ve İdari Bilimler Fakültesi, Uluslararası İlişkiler, mhmbektas@uludag.edu.tr

**** Dr.Öğr.Üyesi, Bursa Teknik Üniversitesi, İnsan ve Toplum Bilimleri Fakültesi, İşletme Bölümü, burcu.bilir@btu.edu.tr

***** Araş. Gör., Bursa Uludağ Üniversitesi, İktisadi ve İdari Bilimler Fakültesi, Uluslararası İlişkiler, talipalan@uludag.edu.tr

Bu makale iThenticate sistemi tarafından taranmıştır.

Makale Gönderim Tarihi: 6 Eylül 2019 
amacı, Bursa Uludağ Üniversitesi'nde eğitim almakta olan yabancı uyruklu öğrencilere anket yoluyla ulaşıp, "Yabancı öğrenciler üniversitemizde eğitim almaya başladıktan sonra kendilerindeki Türkiye imajında bir değişiklik oldu mu, olduysa bunun nedenleri nelerdir?" sorularına karşılık bulmaya çalışmaktır. Buradan elde edilen verilere, gerek hâlihazırda ülkemizde bulunan gerekse ileride gelecek olan yabancı uyruklu öğrencilerdeki Türkiye imajını daha da iyileştirmek amacıyla geliştirilecek politikaların oluşturulmasında somut kaynak olarak başvurulabilecektir.

Anahtar Kelimeler: Türkiye İmajı, Yabancı Uyruklu Öğrenci, İletişim Hipotezi 


\begin{abstract}
There has been a significant increase in the number of international students in Turkey in recent years. The majority of international students reflects a temporary population, as they leave country when they complete their degree. However, temporary population could have long-term outcomes for the hosting country. The developed Turkey's image in international students after spending some time in our country could be assessed as a key impact of long-term results. It is therefore important to ascertain how Turkey's image for international students has altered after they have spent some time in Turkey. The current study used questionnaire to reach international students who studies at Bursa Uludag University in order to discover whether there is any change in their view about Turkey's image since they have begun their study, and if there is, then what reasons lie behind this change. The findings of the current research could provide a guidance to develop policy in order to improve Turkey's image for present and forthcoming international students.
\end{abstract}

Key Words: Turkey's image, international students, contact hypothesis 


\section{Giriş}

Küreselleşen dünyada teknolojinin etkisiyle her alanda yaşanan hızlı değişimler eğitim alanını da etkilemektedir (Yıldıran vd., 2016:20). Küreselleşmeyle birlikte ulaşım ve iletişim olanaklarının gelişmesi, insanların farklı ülkelere gidip orada eğitim almalarını daha da kolaylaştırmıştır. Kalkınma Merkezi Araştırmaları'nın 2015 tarihli raporunda da ifade edildiği üzere:

Yirminci yüzyılın ikinci yarısından itibaren dünyada meydana gelen hızlı değişim pek çok alanda olduğu gibi yükseköğretim alanında da kendini göstermiştir. Az gelişmiş ülkelerin kalkınma çabalarındaki yükseliş, gelişmiş ülkelerin nitelikli insan gücüne duydukları gereksinim, artan küreselleşmenin getirdiği seyahat kolaylığı, ülkeler arasında işbirliği ve etkileşimin artması, üretim ilişkilerinin değişmesi, artan nüfus, kişilerin kendi ülkelerinin dışında farklı bir entelektüel birikimden yararlanma isteği ve daha pek çok sebep günümüzde uluslararası öğrenci hareketliliğinin önemli bir seviyeye ulaşması sonucunu doğurmuştur (KAM Raporu, 2015: 10).

Yakın dönem içerisinde, yabancı uyruklu öğrencilere yönelik pazar hacmi önemli oranda gelişmiştir. Başta gelişmiş ülkeler olmak üzere dünyanın birçok yerinde yabancı uyruklu öğrencilerin kaynaklık ettiği önemli bir ekonomik değer söz konusudur (Levent ve Karaevli, 2013: 98). Filhakika, bazı ülkeler kendileri için önemli bir gelir kalemi olan bu sektörden daha fazla kazanç elde etmek amacıyla yatırım yapmaktadır. Yapılan yatırımlarla ülkenin yabancı öğrencilerdeki imaj değeri yükseltilip, onlar için bir marka ülke olmaya çalışılmaktadır. Bu bağlamda, özellikle gelişmiş ülkeler, yabancı uyruklu öğrencilerin beklentilerini ve ülkelerine ilişkin fikirlerini ölçmek amacıyla araştırmalar yapmakta ve bu araştırmalardan elde edilen verilerle yabancı öğrencilere yönelik daha sağlıklı politikalar geliştirmeye çalışmaktadır.

Şüphesiz en bilindik ortak neden olan İngilizce öğrenme amacını ${ }^{1}$

1 Bilhassa Anglosakson ülkelerine seyahat eden yabancı uyruklu öğrenciler için temel amaç olarak karşımıza çıkmaktadır. 
göz ardı edecek olursak, yabancı uyruklu öğrencilerin kendi ülkelerinden çıkıp bazen binlerce kilometre uzakta dünyanın farklı coğrafyalarında öğrenim görmek istemelerinin temelinde, genel olarak, yüksek hayat koşullarının gölgesinde daha kaliteli bir eğitim alma ve burs imkânlarından yararlanma arzusu yatmaktadır. ${ }^{2}$

Ülkemizde yakın dönem içerisinde yabancı uyruklu öğrenci sayısında önemli oranda artış olmuştur. Gerek resmi dilin Türkçe olması gerekse birçok üniversitede eğitim dilinin Türkçe olması hasebiyle, İngilizce gibi popüler ve uluslararası sistemde baskın olan bir dili öğrenme amacının bu artışta pek bir katkısının olmadığını söyleyebiliriz. Bu artışta daha çok, gerek ülkenin cazip imkânlara sahip oluşu gerekse yakın dönemde yabancı öğrencilerin gelmelerini teşvik eden programların geliştirilmesinin etkili olduğunu söyleyebiliriz. Yabancı uyruklu öğrencilerin sayısının artması, kısa ve orta vadede hem eğitim kalitesini olumlu etkileyebilmekte hem de çeşitliliğin artmasına öncülük edebilmektedir. Bununla beraber, uzun vadede de ülkemiz açısından birtakım sonuçları olabilmektedir. Bu noktada, ülkemizde belirli bir süre kaldıktan sonra kendi ülkelerine veya başka ülkelere taşınan yabancı öğrencilerde oluşan Türkiye imajı, uzun vadeli sonuçların en önemli etkenlerinden bir tanesidir. Zira birbirlerini tanyan toplumlar arasında ilişkiler de daha verimli bir şekilde gelişir (Anholt, 2011: 300).

Mevcut çalışma, Bursa Uludağ Üniversitesi'nde eğitim almakta olan yabancı uyruklu öğrencilere anket yoluyla ulaşıp, "Yabancı öğrenciler üniversitemizde eğitim almaya başladıktan sonra kendilerindeki Türkiye imajında bir değişiklik oldu mu, olduysa bunun nedenleri nelerdir?" sorularına karşılık bulmaya çalışmıştır. Bununla beraber, yabancı uyruklu öğrencilerin vakitlerini en çok geçirdikleri ve en çok muhatap oldukları kurum olan üniversitelerimiz, sade-

2 Bu noktada, kişilerin koşulları ile motivasyonları arasında bir nedensellik bağı bulunmaktadır. Şöyle ki aile refahı yüksek ama ülke refah düzeyi düşük olanlar ağırlıklı olarak refah düzeyi yüksek ülkelerde daha kaliteli bir eğitim alma amacı güderken, hem aile hem de ülke refah düzeyi düşük olanlar ise ağırlıklı olarak refah düzeyi yüksek ülkelerde burs imkânlarından istifade etmek amacı gütmektedirler. 
ce Türkiye'ye değil, uluslararası çevreye de hitap eden bir aktör konumundadır. Dolayısıyla, üniversitelerimize gelen öğrencilerin öğrenim aldıkları üniversite hakkındaki izlenimleri, Türkiye hakkındaki izlenimlerinin temelini oluşturabilmektedir. Diğer bir ifadeyle, üniversitenin yabancı uyruklu öğrencilerdeki imaj değeri, bir bakıma Türkiye'nin imaj değerini oluşturmada öncülük edebilmektedir. Bu noktada, yabancı uyruklu öğrencilerdeki gelmeden önce mevcut olan Türkiye imajı ile geldikten sonra oluşan Türkiye imajı arasındaki farkın ortaya konulmasının yanında, bulundukları üniversitenin Türkiye'nin imaj değerinin artmasına ne derece katkıda bulunduğu da tespit edilmeye çalışılmıştır. Böyle bir tespit yapılırken üniversitenin katkıları ile birlikte yabancı uyruklu öğrencilerin beklentileri de belirlenmiştir. Mevcut araştırma ile elde edilen tüm veriler, yabancı uyruklu öğrencilerdeki Türkiye imajını etkileyen unsurların zayıf yönlerinin giderilmesinde ve güçlü yönlerinin daha da iyileştirilmesinde yol gösterici olabilir. Böylelikle, yabancı uyruklu öğrencilerin tüm potansiyelleri ile değerlendirilerek Türkiye açısından önemli bir kaynak oluşturulmas1 da mümkün olabilir.

\section{Literatür}

Yabancı uyruklu öğrencilerdeki ülke imajında üniversitelerin rolü üzerine henüz bir çalışma yapılmamıştır. Bununla birlikte, gerek sadece Türkiye'nin imajı ile ilgili gerekse ülkemizdeki yabancı uyruklu öğrencilerin diğer yönleri ile ilgili çalışmalar bulunmaktadır. Mevcut araştırmanın da önemli bir boyutu olan yabancı uyruklu öğrencilerdeki Türkiye'ye gelmeden önce ve geldikten sonraki Türkiye imajı ile ilintili olan çalışmalar mevcuttur. Bunlar arasında, T.C. Kalkınma Bakanlığı tarafından desteklenen ve Kalkınma Araştırmaları Merkezi (KAM) tarafından yürütülen "Yükseköğretimin Uluslararasılaşması Çerçevesinde Türk Üniversitelerinin Uluslararası Öğrenciler İçin Çekim Merkezi Haline Getirilmesi" isimli araştırma projesi, en önemli ve en kapsamlı çalışma olarak karşımıza çıkmaktadır (KAM, 2015). Çalışma ile “Türk üniversitelerine yurt dışından gelen öğrenci sayısının artırılması için yapılması gereken iyileştirme ve düzenlemelerin tespit edilmesi ve politika önerileri olarak ilgili kurumların değerlendirmesine sunulması 
amaçlanmıştır" (KAM, 2015). Böyle kapsamlı bir çalışmanın yanı sıra, yabancı öğrenciler konusunu hususi bir yönüyle ele alan çalışmalar da olduğu görülmektedir. Bu çalışmalardan biri, makale olarak yayınlanan “Kayseri’de Öğrenim Gören Yabancı Uyruklu Öğrencilerin Kayseri, İslam, Türkiye Algısı" başlıklı yüksek lisans tezidir (Göver ve Yavuzer; 2015). Bu çalışmada, Türkiye algısına ilişkin ulaşılan bulgulara bakıldığında, öğrencilerin Türkiye'ye gelmeden önceki algısı ile geldikten sonraki algısı arasında değişiklik olduğu tespit edilmiş ve söz konusu bu değişimin bir kısmının pozitif bir kısmının ise negatif olduğu belirtilmiştir (Göver ve Yavuzer; 2015: 1027). Bu bağlamda çalışma, Türkiye hakkında olumlu intiba edinimi sağlayabilmek adına gerekli tedbirlerin alınması lüzumunu da vurgulamıştır (Göver ve Yavuzer, 2015: 1028).

Diğer bir çalışma yine makale olarak yayınlanan "Türk Cumhuriyetlerinden Gelen Öğrencilerin Türkiye Cumhuriyeti Vatandaşlarına Karşı Taşıdıkları Kalıp Yargılar" başlıklı bir yüksek lisans tezidir (Karabayev ve Tutkun, 2001). Bu çalışma, Türkiye'ye olumlu yargılarla gelen öğrencilerin, bir süre Türkiye'de kaldıktan sonra olumsuz yargılara sahip olduklarını, zihinlerinde oluşturdukları olumlu Türkiye imajının Türkiye'yi tanıdıkça olumsuzlaştığını ileri sürmektedir (Karabayev ve Tutkun, 2001: 18). Yaklaşık 20 yıl önce yapılmış olan bu çalışmanın yanı sıra, yakın dönem içerisinde yapılmış olan “Güney Kafkasya Kökenli Öğrencilerin Türkiye'ye Gelmeden Önceki ve Geldikten Sonraki Türkiye Alg1larının Değişimi" adlı bir başka çalışmaya bakıldığında da benzer sonuçların çıktığını görüyoruz. Hedef örneklemi Güney Kafkasyalı öğrenciler olan bu çalışma, Türkiye'ye geldikten sonra öğrencilerin Türkiye algısının genel olarak olumsuz yönde değiştiği sonucuna ulaşmıştır (Bozkuş ve Arı, 2017: 52-53).

$\mathrm{Bu}$ iki çalışmadaki bulgular, ilk bakışta, mevcut çalışmada test edilen Allport'un iletişim hipotezinin doğruluğunu sorgulatabilir. Ancak, iletişim hipotezinden var olan olumlu algıdaki değişim değil var olan olumsuz yargı değerindeki değişim anlaşılmalıdır (Pettigrew \& Tropp, 2005: 262). Diğer bir ifadeyle, var olan olumsuz algı değerinin olumluya dönmesi, sabit kalması veya 
daha olumsuza dönmesi ile var olan olumlu alg1 değerinin azalması veya artması ayrı ayrı değerlendirilmelidir (Pettigrew, 1998: 65; Pettigrew \& Tropp, 2005: 262; Miller, 2002: 387). Zira var olan olumlu yargılar beklentilerin çok yüksek tutulması ile ilgili olabilir ki; bu da iletişim hipotezinin test edilmesi için gerekli şartlarla uyuşmamaktadır. Filhakika, iletişim hipotezinin odak noktası olumsuz ön yargılardır (Pettigrew \& Tropp, 2005: 262; Miller, 2002: 387). Bu yüzden, hedef örneklemde var olan olumlu yarg1lardaki değişim ile var olan olumsuz yargılardaki değişimin ayrı ayrı değerlendirilmesi gerekir.

Bu bağlamda, konusu Türkiye algısı olan ve 2010-2011 yıllarında Bilge Adamlar Stratejik Araştırmalar Merkezi (BİLGESAM) tarafından gerçekleştirilen “Ermenistan'da Türk ve Türkiye” algısı üzerine yapılmış anket çalışması bize önemli ipuçları sunmaktadır (Akyürek ve Bilgiç, 2012). Bu çalışmada hedef örneklemler doğrudan yabancı uyruklu olmasa da katılımcıların çoğu üniversite öğrencileri ve akademisyenlerden oluşmaktadır (Akyürek ve Bilgiç, 2012: 2). Bu çalışma ile yapılan anket sonuçlarına bakıldığında, Türkiye' yi ziyaret etmiş olan katılımcıların Türkiye algısının, Türkiye'yi ziyaret etmemiş olanlarınkine nazaran çok daha olumlu olduğu görülmektedir (Akyürek ve Bilgiç, 2012: 21). Bu çalışma da, Allport'un iletişim hipotezini destekler mahiyette, iki toplumun birbirlerini tanıyıp-tanımamasının olumsuz algılar üzerinde etkili olduğunu savunmuştur (Akyürek ve Bilgiç, 2012: 21).

Bazı çalışmalar, konunun özel bir yönü üzerinde durmak yerine genel bir yaklaşım benimseyerek yabancı uyruklu öğrencilerin durum analizini yaparken (Yıldıran ve diğerleri, 2016), bazıları da bütünleşme sorunları veya yabancı uyruklu öğrencilerin yaşadıkları sorunlar üzerine yoğunlaşmıştır (Çoşkunserçe ve Erişti, 2017; Güçlü, 1996; Köylü, 2001; Paksoy ve diğerleri, 2012). Bunlara ek olarak, bazı sosyal bilimciler de ülkemizdeki yabancı uyruklu öğrencilerin, bütünleşme paralelinde, ruhsal sorunlarını incelemiştir (Annaberdiyev, 2006). Ayrıca bazı çalışmalarda, Türkiye'nin imajına ilişkin olarak genel değerlendirmeler yapılmış ancak Türkiye'nin imajı hususi olarak yabancı uyruklu öğrencilerin gözünden incelenmemiştir (Gültekin, 2005; Saran ve Karpat, 2002). 
Son olarak, bazı çalışmalar da, ülkemiz açısından barındırdığı potansiyele değinerek, uluslararasılaşma sürecinin yanı sıra uluslararası öğrenci hareketliliğinden elde edilebilecek pazar payına dikkat çekmiştir (Şimşek ve Bakır, 2016: 541).

Dünyada yabancı uyruklu öğrenci sayısı 2000 yılında 2 milyon iken, bu sayı 2017 yılında 5,3 milyona ulaşmıştır (UNESCO, 2019). Sayının önemli oranda artış göstermesi devletler açısından yeni bir kaynak anlamına gelmektedir. Zira eğitim müşterisi olarak niteledikleri yabancı uyruklu öğrenciler, onlar için birçok anlamda kazanç elde etme aracıdır. Bu bağlamda, yabancı uyruklu öğrenciler eğitim amacıyla bir başka ülkeye vardıklarında, giderlerini karşılamak için kendi ülkelerinden sürekli sıcak para taşımakta, ${ }^{3}$ bu da ev sahibi ülke için önemli bir ekonomik kaynak anlamına gelmektedir. Dolayısıyla, İngiltere, Amerika Birleşik Devletleri, Avustralya, Kanada, Almanya ve Fransa gibi gelişmiş ülkeler, yabancı uyruklu öğrenciler için bir merkez olmaya çalışmaktadır (UNESCO, 2009). Filhakika, bu ülkelerdeki yabancı uyruklu öğrenci sayısı oldukça fazladır. ${ }^{4}$ Böyle bir eğilimin temelinde, bu sektörden azami ölçüde istifade edebilme amacı yatmaktadır. Bu bağlamda, konuya ilişkin çok yönlü araştırmalar yapılarak elde edilen veriler esas alınıp yabancı öğrencilere yönelik politikalar geliştirilmektedir. Sonuç olarak, bu ülkeler yabancı uyruklu öğrenciler sektöründen gerek ekonomik gerekse bilimsel olarak çok verimli bir şekilde istifade edebilmektedir. Bu ülkelerin yabancı uyruklu öğrenciler için cazibe merkezi olmasında imajlarının payı

3 Yabancı uyruklu öğrencilerin küçük bir kısmı burslu veya gittikleri ülkede çalışarak giderlerini karşılıyor. Burslar da genellikle başarılı öğrencilere temin edilmekte, bu öğrenciler ağırlıklı olarak gittikleri ülkenin imkânlarından dolayı orada kariyerlerine devam etmektedirler. Aslında bu da uzun vadede dünyadaki başarılı insanların ev sahibi ülkeye katkı sunması anlamina gelebilmektedir.

4 ABD' de 1.2 milyon (SEVIS by the Numbers, 2018), Avustralya' da 1.3 milyon (OECD, 2020), Kanada' da 572,415 (Canadian Bureau for International Education, 2020), İngiltere'de 485,645 (Study in UK, 2020) yabancı uyruklu öğrenci bulunmaktayken, Türkiye'de de bu sayı yakın dönemden beri hızla artış göstererek 114,620 yabancı uyruklu öğrenci bulunmaktadir (OECD, 2020). 
çok yüksektir. Ülkemizde ise konuya ilişkin olarak, yakın dönemde yabancı uyruklu öğrenci sayısındaki artışla beraber, yabancı uyruklu öğrencilerin bütünleşme sorunları üzerine birtakım çalışmalar yapılmıştır. Ancak, mevcut durumların analizi ile beraber, "yabancı uyruklu öğrenciler sektöründen nasıl daha etkin bir şekilde istifade edilebilir?" gibi sorulara yanıt arayan müessir ve ileriye dönük araştırmalara daha çok ihtiyaç duyulmaktadır. Bu bağlamda, Türkiye'nin imajı ve bunu etkileyen faktörleri tespit eden çalışmaların artması önem arz etmektedir. Mevcut çalışma da Türkiye' de eğitim alan yabancı uyruklu öğrencilerin gözünden Türkiye imajı konusunda bir araştırma sunarak literatüre katkı sağlamaya çalışmıştır.

\section{Araştırmanın Amacı}

Bu çalışmanın amacı, Türkiye'de öğrenim görmekte olan yabancı uyruklu öğrencilerdeki Türkiye imajında ülkemize geldikten sonra olumlu bir değişim olup olmadığını iletişim hipotezi çerçevesinde test etmektir. Gordon W. Allport'a (1979) atfedilen "iletişim hipotezi"nde (contact hypothesis), birbirini tanımayan gruplar veya çatışma halinde olan gruplar birbirleriyle vakit geçirmeye başlayıp iletişim halinde olunca, gruplar arasındaki olumsuz alg1lamaların azaldığı kabul edilmektedir.

Yabancı uyruklu öğrencilere dair yapılan çalışmaların daha çok onların bütünleşme süreçlerine yoğunlaştığı gözlemlenmektedir. Türkiye' de yakın tarihten itibaren sayıları gittikçe artış eğiliminde olan yabancı uyruklu öğrenciler, Türkiye açısından ciddi potansiyeli olan bir sektörü ifade etmektedir. Ancak, bu sektörden daha aktif bir şekilde istifade etmek ve ülkemiz lehine işleyen bir sistem oluşturabilmek için sektördeki aktörlerin tercihlerini ve düşüncelerini etkileyen faktörlerin iyi bilinmesi gerekmektedir.

Mevcut çalışma ile Bursa Uludağ Üniversitesi'nde öğrenim gören farklı fakültelerdeki ve sınıflardaki yabancı uyruklu öğrencilerin Türkiye'ye geldikten sonra gözlerindeki Türkiye imajında değişikliklerin olup olmadığının incelenmesinin yanında, eğer bir değişim olduysa bu değişim sürecindeki etkenlerin neler olduğu da tespit edilmeye çalışılmıştır. Böylelikle, yabancı uyruklu öğrenci 
sektörünün barındırdığ1 potansiyeli ülkemizin lehinde ortaya çıkarmaya yarayacak bulgular elde edilmiş olacaktır. Mesela, Bursa Uludağ Üniversitesi'nin tanınırlığını artırmada yabancı uyruklu öğrencilerin daha etkin kullanılmasına olanak sağlayacak politikalar hakkında fikir verebilecektir. Bu amaçla gerçekleştirilecek bir çalışmanın, hem mevcut durumu nedenleri ile birlikte açıklamada hem de bu doğrultuda ileriye yönelik iyileştirme çalışmalarında rehberlik edeceği düşünülmektedir.

\section{Araştırmanın Kapsamı ve Örneklem Dağılımı}

Çalışma kapsamında, Türkiye' de çok fazla ele alınmayan yabancı uyruklu öğrencilerin gözünde Türkiye imajı hususunda "iletişim hipotezi" nin test edilip istatistiksel olarak ortaya konulmasına yönelik bir anket yapılmış ve sonuçları faktör analiziyle ölçülmüştür. Çalışmanın en önemli ayağı olan anket uygulamasının ana kitlesini oluşturan Bursa Uludağ Üniversitesi Türkçe Öğretimi Uygulama ve Araştırma Merkezi'nde (ULUTÖMER) okuyan yabancı uyruklu aktif öğrencilerin sayısı 400 ve Bursa Uludağ Üniversitesi İktisadi ve İdari Bilimler Fakültesi'nde (İIBF) okuyan yabancı uyruklu aktif öğrencilerin sayısı yine 400 civarındadır. Buna göre, $\% 5$ hata payı ve \%95 güven aralığında örneklem büyüklüğü 174 olarak hesaplanmıştır. Araştırmada üst düzey analizler yapılacağ1 için, örneklemde 200 yabancı uyruklu öğrenciye anket uygulanması hedeflenmiştir. Yapılan anket çalışmaları sonucunda 169 tane sağlıklı veri içeren ankete ulaşılmıştır.

Buna ek olarak, araştırmanın hedef örneklemleri sadece lisans öğrencilerinden oluşmamaktadır. ULUTÖMER'deki hedef örneklemler, okuyacakları lisans programları için gerekli olan Türkçe eğitimini alan öğrenciler iken, İ̈BF'deki hedef örneklemler ağırlıklı olarak lisans öğrencisi olmakla beraber yüksek lisans ve doktora seviyesinde öğrenim gören öğrencilerden de oluşmaktadır. Bu bağlamda, yapılan ankete lisansüstü düzeydeki öğrenciler de katılmıştır. Bursa Uludağ Üniversitesi'nin tüm birimlerine genelleştirilebilecek verilere ulaşılması çalışma açısından önem arz etmektedir. Bu amaçla, araştırmanın ana evrenlerinden biri olarak ULUTÖMER belirlenmiştir. İ̈BF, 10.763 toplam lisans öğrenci sayısıyla Üniversitenin en kalabalık fakültesini teşkil etmektedir 
ve önemli sayıda yabancı uyruklu öğrenciye sahiptir. İIBB, hedef örneklemlerin çoğunu kapsayan bir evren olması ve anket uygulamasında hedef örneklemlere ulaşmada kolaylık sağlaması nedeniyle diğer ana evren olarak seçilmiştir.

Mevcut araştırma ile cevaplanmaya çalışılan sorular şöyledir: İlk olarak, yabancı uyruklu öğrencilerin Türkiye'ye gelmeden önceki Türkiye imajı ile Türkiye'ye geldikten sonraki Türkiye imajı arasında nasıl bir fark vardır? İkinci olarak, gelmeden önce ve geldikten sonraki süreçte Türkiye'ye bakış açılarını etkileyen faktörler nelerdir? Bu bağlamda, özellikle öğrencilerin öğrenim gördükleri Bursa Uludağ Üniversitesi'nin yabancı uyruklu öğrencilerdeki Türkiye imajı değerine katkısının ölçülmesi amaçlanmıştır.

Bu amaçla, öncelikle Türkiye'de okumakta olan yabancı uyruklu öğrencilerin Türkiye imajını etkileyen faktörler, Türkiye'ye geldikten sonraki Türkiye imajı değeri ile gelmeden önceki değer arasındaki fark, bu değerleri arttırabilecek politikalar geliştirilmesinde oluşturulacak ön veri, Türkiye' de öğrenim gören yabancı uyruklu öğrencilerin akademik, sosyal ve kültürel yaşam alanları hakkındaki beklentileri ve öğrenimleri süresince karşılaştıkları akademik, sosyal ve kültürel sorunlar Bursa Uludağ Üniversitesi'nde yapılan bu alan araştırması ile nedenleri ve sonuçları açısından değerlendirilecektir.

Son olarak, Türkiye' de öğrenim gören yabancı uyruklu öğrenciler denildiğinde, çeşitli burslardan yararlanmak suretiyle veya kendi imkânlarıyla Türkiye'ye gelen yabancı uyruklu öğrenciler anlaşılmalıdır (Demirhan, 2017: 548). Yabancı uyruklu öğrenciler kavramının yerine uluslararası veya denizaşırı öğrenciler kavramları da yaygın olarak tercih edilmektedir. Mevcut çalışma da Türkiye'deki devlet kuruluşlarındaki resmi kullanıma sadık kalarak yabancı uyruklu öğrenci kavramını kullanmıştır.

\section{Araştırmada Başvurulan Yöntem}

Mevcut araştırmada örnekleme yöntemi, değişken tanımları, veri toplama ve veri analiz yöntemleri benimsenmiştir. "Yabancı Uyruklu Öğrencilerdeki Türkiye İmajı: Bursa Uludağ Üniversitesi Örneği" isimli çalışma, bir alan araştırması olarak tasarlanmıştır. Bu 
amaçla, ilk olarak literatür taraması yapılıp konuya ilişkin bir kısım verilere ulaşılmıştır. Böylelikle, literatür taramasından elde edilen verilerin tasnif ve analizi yapılarak çalışmanın teorik boyutu belirlenmiştir. Bu aşamadan sonra, çalışmanın uygulama kısmının çerçevesi oluşturulmuştur. Uygulama kısmı için öncelikle anket soruları hazırlanıp anket formları oluşturulmuştur. Uygulama kısmının son aşamasında bu anket çalışması Bursa Uludağ Üniversitesi'nde öğrenim gören yabancı uyruklu öğrencilere uygulanmıştır. Çalışma bünyesinde, Türkiye' de çok fazla ele alınmayan yabancı uyruklu öğrencilerin gözünde Türkiye imajı hususunda iletişim hipotezinin test edilerek istatistiksel olarak ortaya konulmasına yönelik bir anket yapılmış ve sonuçları faktör analiziyle ölçülmüştür.

Çalışmanın en önemli ayağı olan anket uygulamasının ana evrenini oluşturan ULUTÖMER'de okuyan yabancı uyruklu aktif öğrencilerin sayısı 400 ve Uludağ Üniversitesi İktisadi ve İdari Bilimler Fakültesi'nde okuyan yabancı uyruklu aktif öğrencilerin sayısı yine 400 civarındadır. Buna göre, $\% 5$ hata payı ve $\% 95$ güven aralığında örneklem büyüklügü 174 olarak hesaplanmıştır. Araştırmada üst düzey analizler yapılacağı için, örneklemde 200 yabancı uyruklu öğrenciye anket uygulanması hedeflenmiştir. Seçilen öğrencilere anket uygulanarak araştırma için gerekli olan veriler elde edilmiştir. Elde edilen veriler SPSS 22 istatistik programı ile analiz edilmiştir. Uygulama bölümünden elde edilen veriler teorik bilgiler ışığında değerlendirilerek çalışmanın sonuç kısmı meydana getirilmiştir.

Çalışmada faktör analizinin kullanılması uygun görülmüştür. Faktör analizi, birbirleriyle ilişkili çok sayıdaki değişkeni bir araya getirerek az sayıda, anlamlı ve birbirinden bağımsız faktörler halinde yeni sonuçlar bulmayı amaçlayan ve yaygın olarak kullanılan çok değişkenli istatistik tekniklerinden birisidir (Büyüköztürk, 2002). Bu analiz tekniği, "gözlemlenen çok sayıdaki değişken içerisinden gruplandırılmış temel değişkenler ya da faktörler tanımlayarak değişken sayısını azaltmak amacıyla yapılmakta ve tanımlanan her bir faktör, değişkenler arasındaki ilişkinin ölçülmesi sonucu aynı özelliği ölçen birbiri ile ilişkili değişken setinden oluşmaktadır" (Kalaycı, 2014: 321). Faktör analizi, "değişken- 
ler arasındaki karşılıklı ilişkileri inceleyerek, değişkenlerin daha anlamlı ve özet bir şekilde sunulmasını sağlar. Değişken grupları arasındaki ilişkilerin altında yatan birlikteliğin ortak örüntülerinin hangi faktörler içinde tanımlanacağı, ilişkileri basit anlamda ortaya koyar" (Bayram, 2012: 199). Başka bir ifadeyle, analiz veri grubunda yer alan değişkenler arasındaki ilişkilerin altında yatan ortak özellikleri kurmaya çalışır (Bayram, 2012: 199). Faktör analizi sosyal bilimlerde ölçek geliştirme veya ölçeğin geçerliliğini test etmede kullanılır. Araştırmacı bu analizle ölçmek istediği bilişsel bir yapıyı ölçülebilir gözlenen değişkenlerle açıklamaya çalışır (Büyüköztürk, 2002: 118).

\section{Bulgular}

Araştırmadan elde edilen bulgular toplam üç kısımdan ve 17 tablodan oluşmaktadır. Birinci kısımda katılımcıların demografik özellikleri belirtilmiş, ikinci kısımda yabancı uyruklu öğrencilerdeki Türkiye'ye gelmeden önceki ve geldikten sonraki Türkiye imajı tespit edilmeye çalışılmış ve üçüncü kısımda ise öğrencilerin öğrenim gördükleri Bursa Uludağ Üniversitesi'nin yabancı uyruklu öğrencilerdeki Türkiye imajı değerine katkısının ölçülmesi amaçlanmıştır.

\section{Araştırma Grubunun Demografik Özellikleri}

Aşağıdaki Tablo 1'de çalışmaya katılan 169 öğrencinin cinsiyet dağılımına bakıldığında, görüşülen öğrencilerin \%80,5'i erkeklerden, \%19,5'i kadınlardan oluşmaktadır. Öğrencilerin medeni durumuna bakıldığında ise büyük çoğunluğunun bekâr olduğu, bununla beraber evli öğrencilerin de eğitim amaciyla Türkiye’ye geldiği tespit edilmiştir. Evli öğrencilerin de Türkiye'yi tercih etme eğilimlerinin olması, aslında öğrencilerin Türkiye'yi aileleri için de yaşanılabilecek elverişli bir ülke olarak algıladıklarını göstermektedir.

Öğrencilerin öğrenim gördükleri alanların oranlarının, Fen Bilimleri için \%46,2 ve Sosyal Bilimler için \%53,8 olmak üzere, birbirine yakın olduğu tespit edilmiştir. Yaş durumlarına bakıldığında öğrencilerin yarısından fazlasının 18-23 yaş aralığında olduğu ve 24-29 yaş aralığının ise ikinci büyük orana sahip olduğu tespit 
edilmiştir. Genelde 18-23 yaş aralığının öğrencilerin lise eğitimlerinin sonrasında bulundukları yaş aralığı olduğu düşünüldüğünde, bu öğrencilerin lise eğitimlerinden sonra doğrudan Türkiye'ye gelmeyi tercih ettikleri ve daha lise döneminde, hayatlarının en önemli adımlarından olan lisans eğitimlerini Türkiye endeksli planladıkları söylenebilir. Bu veriden, yabancı uyruklu öğrencilerin büyük kısmı için Türkiye'ye gelmeden önce kendilerindeki Türkiye algısının olumlu olduğu sonucu da çıarılabilir.

Öğrencilerin büyük bölümünü lisans öğrencileri oluştursa da aralarında doktora veya yüksek lisans amaçlı gelen öğrencilerin de bulunmasından, Türkiye'nin salt öğrenme amaçlı değil araştırma yapmak için de tercih edilebilecek bir ülke olarak algılandığ1 sonucuna varılabilir. Üniversiteler öğretme eylemi ile var olan bilgiyi aktarırken, araştırma eylemi ile yeni bilgileri keşfetmeye odaklanırlar. Araştırma ise ciddi alt yapı gerektiren bir özelliktir ve ülkelerin gelişmişlik düzeyleriyle doğrudan bağlantılıdır. Bu sebeple, gelişmekte olan veya az gelişmiş ülkelerde araştırma alt yapısı oldukça kısıtlıdır. Diğer bir husus, lisansüstü eğitimi için (bilhassa doktora için) ülke tercihi yapan öğrenciler, lisans öğrencilerine nazaran daha bilinçli ve seçici hareket etmektedirler. Yabancı uyruklu öğrencilerin gelişmiş ülkeler içerisinde araştırma (doktora) için Türkiye'yi tercih etmeleri, onlardaki olumlu ve güçlü Türkiye imajının bir göstergesidir diyebiliriz.

Öğrencilerin ikamet sürelerine bakıldığında, \%36,7'sinin 1 ila 3 yıl ve $\% 46,1$ ' inin 4 yıl ve üzerinde olması, katılımcıların büyük çoğunluğunun Türkiye'ye gelmeden önceki algılarının yerini, geldikten sonraki algılarının aldığını söyleyebiliriz. Böylece, katılımcıların bu durumu aracılığıyla mevcut araştırma, yabancı uyruklu öğrencilerdeki Türkiye'ye gelmeden önce ve geldikten sonraki Türkiye imajı hakkında daha sağlıklı veriler elde etmiştir diyebiliriz.

Son olarak, öğrencilerin geldikleri bölgelerin coğrafi dağılımına bakıldığında, ağırlıklı bölümün Asyalı öğrencilerden oluştuğu, bunu Afrika, Orta Doğu, Avrupa ve Kuzey Amerika bölgelerinden gelen öğrencilerin takip ettiği tespit edilmiştir. Bu da öğrencilerin çeşitliliğini ve gelişmiş ülkelerden de Türkiye'de öğrenim görme talebinin olduğunu göstermektedir. 
M. H. Mustafa Bektaş - K. Burcu Öngen Bilir - Talip Alan

Tablo 1 Katılımcıların Demografik Özellikleri

\begin{tabular}{|c|c|c|}
\hline Değişkenler & Frekans & Yüzde (\%) \\
\hline \multicolumn{3}{|l|}{ Cinsiyet } \\
\hline Kadın & 33 & 19,5 \\
\hline Erkek & 136 & 80,5 \\
\hline \multicolumn{3}{|l|}{ Medeni Durum } \\
\hline Evli & 19 & 11,2 \\
\hline Bekâr & 146 & 86,4 \\
\hline Boşanmış & 4 & 2,4 \\
\hline \multicolumn{3}{|c|}{ Öğrenim Görülen Bilim Dalı } \\
\hline Sosyal Bilimler & 91 & 53,8 \\
\hline Fen Bilimleri & 78 & 46,2 \\
\hline \multicolumn{3}{|l|}{ Yaş } \\
\hline $18-23$ & 96 & 56,8 \\
\hline $24-29$ & 55 & 32,5 \\
\hline $30-35$ & 13 & 7,7 \\
\hline $36-41$ & 5 & 3,0 \\
\hline \multicolumn{3}{|c|}{ Öğrenim Görülen Program } \\
\hline Lisans & 106 & 62,7 \\
\hline Yüksek Lisans & 15 & 26,6 \\
\hline Doktora & 18 & 10,7 \\
\hline \multicolumn{3}{|l|}{ Sinif } \\
\hline 1 & 57 & 33,7 \\
\hline $2-3$ & 62 & 36,7 \\
\hline 4 & 50 & 29,6 \\
\hline \multicolumn{3}{|c|}{ İkamet Edilen Süre } \\
\hline 1 yıldan daha az & 29 & 17,2 \\
\hline $1-3$ & 62 & 36,7 \\
\hline 4 ve üzeri & 78 & 46,1 \\
\hline
\end{tabular}




\begin{tabular}{|l|c|c|}
\hline \multicolumn{3}{|l|}{ Dünyanın Hangi Bölgesinden Gelindiği } \\
\hline Avrasya & 7 & 4,1 \\
\hline Orta Asya & 44 & 26,0 \\
\hline Afrika & 33 & 19,5 \\
\hline Güney Asya & 28 & 16,6 \\
\hline Avrupa & 12 & 7,1 \\
\hline Doğu Asya & 20 & 11,8 \\
\hline Orta Doğu & 17 & 10,1 \\
\hline Kuzey Amerika & 8 & 4,8 \\
\hline Toplam & 169 & 100,0 \\
\hline
\end{tabular}

\section{Araştırma Grubunun Türkiye İmajı}

Yabancı uyruklu öğrencilere Türkiye hakkındaki izlenimlerine ilişkin sorular yöneltilerek, onlardaki Türkiye’ye gelmeden önceki ve geldikten sonraki Türkiye imajının tespit edilmesi amaçlanmiştır.

Aşağıdaki Tablo 2'de, öğrencilerin çok azının Türkiye hakkında yeterli bilgiye sahip olduğu buna karşın büyük çoğunluğunun Türkiye hakkında yeterli bilgiye sahip olmadığ1 görülmektedir. $\mathrm{Bu}$ da aslında mevcut çalışmaya iletişim hipotezini daha sağlıklı test etme imkânı sağlamaktadır. Zira iletişim hipotezi açısından gerekli bir sütun olan tarafların tanışmadan önce birbirleri hakkında yetersiz bilgi sahibi olması durumunu sağlamaktadır (Allport, 1979: 6). Bu veriler doğrultusunda, ankete katılan yabancı uyruklu öğrencilerin Türkiye' de geçirdikleri sürede elde ettikleri tecrübelerin, onlardaki Türkiye imajı üzerindeki etkisinin daha yüksek olduğunu söyleyebiliriz. Böylelikle, yabancı uyruklu öğrencilerdeki imajı olumlu ya da olumsuz etkileyen faktörlerin kaynağının ağırlıklı olarak Türkiye temelli olduğuna kanaat getirebiliriz. Bununla beraber, yabancı uyruklu öğrencilerin Türkiye'ye gelmeden önce yeterli bilgiye sahip olmaları için tanıtıcı çalışmaların artırılması gerektiği sonucunu da çıkarabiliriz. 
Tablo 2 Türkiye'ye gelmeden önce Türkiye'yi yeterince tanıyor muydunuz?

\begin{tabular}{|l|c|c|}
\hline & Frekans & Yüzde (\%) \\
\hline Çok iyi tanıyordum & 25 & 14,8 \\
\hline Biraz fikrim vardı & 109 & 64,5 \\
\hline Hiç tanımıyordum & 35 & 20,7 \\
\hline Toplam & 169 & 100,0 \\
\hline
\end{tabular}

Aşağıdaki Tablo 3'te, öğrencilerin diğer kaynaklardan elde ettikleri bilgilerin \%75,1'inin olumlu olduğu tespit edilmiştir. Bu veriden hem Türkiye tecrübesi olan arkadaşlarının çoğunda olumlu bir Türkiye imajı olduğu hem de internet ortamında paylaşılan bilgilerin müspet olduğu anlaşılmaktadır.

Tablo 3 Türkiye'ye gelmeden önce diğer kaynaklardan (internet, arkadaşlar) edindiğiniz bilgiler ağırlıklı olarak nasıldı?

\begin{tabular}{|l|c|c|}
\hline & Frekans & Yüzde (\%) \\
\hline Olumlu & 127 & 75,1 \\
\hline Olumsuz & 42 & 24,9 \\
\hline Toplam & 169 & 100,0 \\
\hline
\end{tabular}

Aşağıdaki Tablo 4'te görüldüğü üzere, öğrencilerin \%65,1'lik ağırlıklı çoğunluğunun Türkiye'ye geldikten sonra bakış açılarının olumlu yönde değiştiği tespit edilmiştir. Tablo 5 'te de öğrencilerin Türkiye'ye gelmeden önceki olumsuz algılarının \%74'ünün kısmen ya da tamamen olumlu yönde değiştiği görülmüştür. Tablo 4 ve Tablo 5 birlikte değerlendirildiğinde, Türkiye'ye gelmeden önce öğrencilerde bir takım olumsuz algıların olduğu, ancak ağırlıklı çoğunluğunda bu olumsuz algıların Türkiye'ye geldikten sonra olumlu yönde değiştiği görülmektedir. 
Tablo 4 Türkiye'ye geldikten sonra bakış açınız nasıl değişti?

\begin{tabular}{|l|c|c|}
\hline & Frekans & Yüzde (\%) \\
\hline Olumlu & 110 & 65,1 \\
\hline Olumsuz & 59 & 35,0 \\
\hline Toplam & 169 & 100,0 \\
\hline
\end{tabular}

Tablo 5 Türkiye'ye geldikten sonra, gelmeden önceki olumsuz algılarınız olumlu yönde değişti mi?

\begin{tabular}{|l|c|c|}
\hline & Frekans & Yüzde (\%) \\
\hline Kesinlikle değişti & 40 & 23,7 \\
\hline Hiç değişmedi & 44 & 26,0 \\
\hline Kısmen değişti & 85 & 50,3 \\
\hline Toplam & 169 & 100,0 \\
\hline
\end{tabular}

Tablo 6'da öğrencilerin Türkiye'deki öğrenim tecrübelerinden tüm yönleriyle beraber, genel olarak ne ölçüde memnun kaldıkları hususunda, memnun kaldım diyenler $\% 52,1$ ve çok memnun kaldım diyenler $\% 10,1$ olmak üzere, toplamda $\% 62,2$ 'lik büyük kısmının olumlu görüş bildirdiği görülmektedir.

Tablo 6 Türkiye'deki öğrenim tecrübenizden, tüm yönleri 1ş1ğında, genel olarak ne ölçüde memnun kaldınız?

\begin{tabular}{|l|c|c|}
\hline & Frekans & Yüzde (\%) \\
\hline Hiç memnun kalmadım & 7 & 4,1 \\
\hline Memnun kalmadım & 29 & 17,2 \\
\hline Memnun kaldım & 88 & 52,1 \\
\hline Çok memnun kaldım & 17 & 10,1 \\
\hline Emin değilim & 28 & 16,6 \\
\hline Toplam & 169 & 100,0 \\
\hline
\end{tabular}


Tablo 7'de, öğrencilerin \%75,8'inin Türkiye'de öğrenim görmeyi tercih etmeden önce başka ülkelerdeki üniversitelere başvuruda bulunmadığı görülmektedir. Elde edilen bu veri, yukarıda yaş aralığına ilişkin yapmış olduğumuz "öğrencilerin lise eğitimlerinden sonra doğrudan Türkiye'ye gelmeyi tercih ettikleri ve daha lise döneminde, hayatlarının en önemli adımlarından olan lisans eğitimlerini Türkiye endeksli planladıkları" tespitini destekler niteliktedir.

Tablo 7 Türkiye'de öğrenim görmeyi tercih etmeden önce başka ülkelerdeki üniversitelere de başvuruda bulundunuz mu?

\begin{tabular}{|l|c|c|}
\hline & Frekans & Yüzde (\%) \\
\hline Evet & 41 & 24,2 \\
\hline Hayır & 128 & 75,8 \\
\hline Toplam & 169 & 100,0 \\
\hline
\end{tabular}

Sonuç olarak, yabancı uyruklu öğrencilerdeki Türkiye imajının Türkiye'ye gelmeden önce genel olarak olumlu olmasina rağmen, olumsuz algıların da mevcut olduğu görülmüştür. Ancak, Türkiye'ye geldikten sonra olumlu algı değerinin artmasıyla beraber, var olan olumsuz algıların büyük çoğunluğunun da olumluya döndüğü tespit edilmiştir.

\section{Araştırma Grubunun Türkiye İmajını Etkileyen Faktörler}

Yukarıda da değinildiği gibi yabancı uyruklu öğrencilerdeki Türkiye imajı değerinin olumlu yönde değiştiği tespit edilmiştir. Bu artışta ülkemizin birçok dinamiği etkili olsa da -öğrencilerin vakitlerini çoğunlukla kampüste geçirdikleri dikkate alındığında- kampüs ortamının etkisinin daha fazla olduğu söylenebilir. Bu bağlamda, bu kısımda, öğrencilerin öğrenim gördükleri Bursa Uludağ Üniversitesi'nin yabancı uyruklu öğrencilerdeki Türkiye imajı değerinin artmasına olan katkısının ölçülmesi amaçlanmıştır. Bu amaçla, Üniversite'ye başvuru öncesi ve sonrası süreçlere ilişkin tecrübeleri öğrencilere sorulmuştur. Böylelikle öğrencilerin memnun kaldıkları hususlar tespit edilmekle beraber, yetersiz buldukları ve dolayısıyla iyileştirilmesi gereken öncelikli alanlar 
da tespit edilmeye çalışılmıştır. Bu bağlamda aşağıdaki tablolar incelendiğinde genel olarak öğrencilerin memnun olduğu görülse de bazı öğrencilerin üniversiteye başvuru sürecine ilişkin bazı problemler yaşadığı da tespit edilmiştir.

Tablo 8 ve Tablo 9'a bakıldığında öğrencilerin belli bir kısmının kampüse ilk vardıklarında ne yapacaklarına dair fikirleri olduğu ancak geriye kalan çoğunluğun ise ya kısmen ya da tamamen ne yapacaklarını bilmedikleri tespit edilmiştir. Bu bağlamda, yabancı uyruklu öğrencilere kampüse varmadan önce onlara yol gösterecek bir pusula sunulabilir, eğer mevcutsa iyileştirilebilir. Buna ek olarak, kampüse vardıktan sonra öğrencilerin danışabileceği danışma birimleri kurulabilir veya mevcutsa sayıları artırılabilir.

Tablo 8 Kampüse ilk vardığımda ne yapacağımı biliyordum

\begin{tabular}{|l|c|c|}
\hline & Frekans & Yüzde (\%) \\
\hline Kesinlikle katılmıorum & 26 & 15,4 \\
\hline Katılmıyorum & 48 & 28,4 \\
\hline Kararsızım & 41 & 24,3 \\
\hline Katıliyorum & 39 & 23,1 \\
\hline Kesinlikle katıllyorum & 15 & 8,9 \\
\hline Toplam & 169 & 100,0 \\
\hline
\end{tabular}

Tablo 9 Üniversiteye başvuru öncesi ve sonrası süreci takip etmek için sunulan imkânlar yeterliydi

\begin{tabular}{|l|c|c|}
\hline & Frekans & Yüzde (\%) \\
\hline Kesinlikle katılmiyorum & 18 & 10,7 \\
\hline Katılmiyorum & 33 & 19,5 \\
\hline Kararsızım & 58 & 34,3 \\
\hline Katılıyorum & 43 & 25,4 \\
\hline Kesinlikle katıliyorum & 17 & 10,1 \\
\hline Toplam & 169 & 100,0 \\
\hline
\end{tabular}


Aşağıdaki Tablo 10'da görüldüğü üzere, üniversite personelinin sunmuş olduğu hizmetlere ilişkin genel olarak bir memnuniyet olsa da bunu artırıcı birtakım iyileştirmeler de yapılabilir. Zira ülkemize henüz gelen yabancı uyruklu öğrencilerin, ilk zamanlarda gerek dil konusunda gerekse uyum sağlama hususunda zorlanmaları yüksek bir ihtimaldir. Bu yüzden, yabancı öğrenciler ile iletişim kuracak olan personelin, bu bilinç ile hareket edip yabancı uyruklu öğrencilerin işlemlerini gerçekleştirme hususunda daha sabırlı ve anlayışlı olması gerekebilecektir. Bu amaçla, personele, yabancı uyruklu öğrenciler ile iletişim kurarken onlara diğer öğrencilere nazaran daha fazla anlayış göstermeleri yönünde bilgilendirme yapılabilir ve telkinlerde bulunulabilir.

Tablo 10 Üniversite çalışanları (öğrenci işleri, idari personel vb.) çok yardımcı oldular

\begin{tabular}{|l|c|c|}
\hline & Frekans & Yüzde (\%) \\
\hline Kesinlikle katılmiyorum & 17 & 10,1 \\
\hline Katılmiyorum & 27 & 16,0 \\
\hline Kararsizım & 47 & 27,8 \\
\hline Katıliyorum & 59 & 34,9 \\
\hline Kesinlikle katıliyorum & 19 & 11,2 \\
\hline Toplam & 169 & 100,0 \\
\hline
\end{tabular}

Tablo 11, 12 ve 13'e bakıldığında üniversitenin web sitesi hakkında öğrencilerin belli bir kısmı olumlu görüş bildirse de önemli bir kısmı için sitenin yetersiz olduğu tespit edilmiştir. Bu doğrultuda, üniversitenin web sitesi yabancı uyruklu öğrenciler için daha açıklayıcı hale getirilebilir, yabancı uyruklu öğrencilerin web sitesi yoluyla anlamakta güçlük çektiği hususları e-mail veya telefon yoluyla sorabilecekleri ve hızlı iletişim kurabilecekleri iletişim mekanizmaları geliştirilebilir veya bunlar mevcutsa iyileştirilebilir. 
Tablo 11 Üniversite'nin web sitesi başvuru öncesi ve sonrası için çok yardımcı oldu

\begin{tabular}{|l|c|c|}
\hline & Frekans & Yüzde (\%) \\
\hline Kesinlikle katılmiyorum & 12 & 7,1 \\
\hline Katılmiyorum & 35 & 20,7 \\
\hline Kararsızım & 51 & 30,2 \\
\hline Katılıyorum & 50 & 29,6 \\
\hline Kesinlikle katıliyorum & 21 & 12,4 \\
\hline Toplam & 169 & 100,0 \\
\hline
\end{tabular}

Tablo 12 Üniversite web sitesinde istediğim bilgilere ulaşmakta hiç zorluk çekmedim

\begin{tabular}{|l|c|c|}
\hline & Frekans & Yüzde (\%) \\
\hline Kesinlikle katılmiyorum & 15 & 8,9 \\
\hline Katılmiyorum & 32 & 18,9 \\
\hline Kararsızım & 46 & 27,2 \\
\hline Katılıyorum & 62 & 36,7 \\
\hline Kesinlikle katıliyorum & 14 & 8,3 \\
\hline Toplam & 169 & 100,0 \\
\hline
\end{tabular}

Tablo 13 Üniversite web sitesinde yeterli bilgi olmadığı için zorlandım

\begin{tabular}{|l|c|c|}
\hline & Frekans & Yüzde (\%) \\
\hline Kesinlikle katılmiyorum & 18 & 10,7 \\
\hline Katılmiyorum & 41 & 24,3 \\
\hline Kararsızım & 51 & 30,2 \\
\hline Katılıyorum & 39 & 23,1 \\
\hline Kesinlikle katıliyorum & 20 & 11,8 \\
\hline Toplam & 169 & 100,0 \\
\hline
\end{tabular}


Tablo 14'e bakıldığında, araştırmaya katılan öğrencilerin yaklaşık \%90'ının, Bursa Uludağ Üniversitesi bünyesindeki çalışanların ve birimlerin yabancı uyruklu öğrencilerin uyum sağlamalarına ciddi anlamda katkısı olduğunu düşündüğü görülmektedir. Bu bağlamda, Türkiye'ye geldikten sonra öğrencilerdeki Türkiye imaj1 değerindeki yükselişte Bursa Uludağ Üniversitesi'nin önemli bir etken olduğu sonucuna varılabilir.

Tablo 14 Bursa Uludağ Üniversitesi birimleri ve çalışanlarının (Öğrenci İşleri, ULUTÖMER) sizin uyum sağlamanıza katkısı oldu mu?

\begin{tabular}{|l|c|c|}
\hline & Frekans & Yüzde (\%) \\
\hline Kesinlikle olmadı & 24 & 14,2 \\
\hline Kismen oldu & 84 & 49,7 \\
\hline Kesinlikle oldu & 61 & 36,1 \\
\hline Toplam & 169 & 100,0 \\
\hline
\end{tabular}

Tablo 15 ve 16'ya bakıldığında, öğrencilerin ağırlıklı çoğunluğunun hem Bursa Uludağ Üniversitesi'ni hem de Türkiye'de öğrenim görmeyi başka öğrencilere tavsiye edeceğini belirttiği anlaşılmaktadır. Aslında bu da, yabancı uyruklu öğrenciler Türkiye'ye geldikten sonra, Türkiye imajlarındaki yukarıda değinilen olumlu yönde değer artışının bir neticesidir.

Tablo 15 Bursa Uludağ Üniversitesi'ni başka uluslararası öğrencilere tavsiye eder misiniz?

\begin{tabular}{|l|c|c|}
\hline & Frekans & Yüzde (\%) \\
\hline Evet & 106 & 62,7 \\
\hline Hayir & 63 & 37,3 \\
\hline Toplam & 169 & 100,0 \\
\hline
\end{tabular}




\section{Sonuç}

Yukarıdaki veriler dikkate alındığında, öncelikle, araştırma anketine katılanları Türkiye'ye gelmeden önce Türkiye hakkındaki kanaatleri açısından, sayılarına göre sırasıyla, üç kategoriye ayırabiliriz: ilk grup Türkiye'ye gelmeden önce Türkiye hakkında pek fazla bilgisi olmayanlar, ikinci grup Türkiye hakkında Türkiye'ye gelmeden önce olumlu bilgi sahibi olanlar ve üçüncü grup Türkiye'ye gelmeden önce Türkiye hakkında hem olumlu hem olumsuz bilgi sahibi olanlar. Yukarıda da değinildiği üzere, ağırlıklı çoğunluğu ilk grup oluşturmakta ve bu grubun Türkiye'ye geldikten sonra Türkiye algısı büyük oranda olumlu olarak gelişmiştir. İkinci gruptakiler ise Türkiye'ye geldikten sonra gelmeden önce sahip oldukları algıda ciddi bir değişiklik yaşamamıştır. Üçüncü gruptakilere bakıldığında, onlardaki Türkiye imajı da Türkiye'ye geldikten sonra büyük oranda olumlu yönde seyretmiştir. Ezcümle, Türkiye'ye geldikten sonra öğrencilerdeki Türkiye imaj değerinin arttığı ve daha önce var olan olumsuz algıların da büyük oranda olumluya dönüştüğü görülmüştür. Bu noktada iletişim hipotezinin büyük ölçüde doğrulandığı görülmektedir.

İkinci olarak, bu olumlu artışta, başta genel olarak Türkiye' nin sunmuş olduğu zengin imkânların ve Bursa Uludağ Üniversitesi'nin yabancı uyruklu öğrencilere sunmuş olduğu olanakların çok önemli katkıları olduğu da tespit edilmiştir. Bununla birlikte, aşağıdaki hususlarda yapılacak geliştirmelerin önemli olduğu sonucuna varılmıştır:

- Üniversite web sitesinin geliştirilmesiyle yabancı uyruklu öğrenciler için daha anlaşılır hale getirilmesi gerekmektedir. Zira öğrencilerin üniversiteye varmadan üniversite kayıt işlemleri, ulaşım ve konaklama imkânları hakkında yeterli bilgi sahibi olmaları önem arz etmektedir. Bu sağlandığı takdirde, öğrencilerin üniversiteye vardıktan sonra çevreye daha rahat uyum sağlamaları mümkün olacaktır. Böylelikle, öğrencilerin yaşayabilecekleri olumsuz tecrübeler de azaltılmış olacaktır. 
- Yabancı uyruklu öğrenciler ile iletişim mekanizmalarının iyileştirilmesi belki de en önemli noktayı temsil etmektedir. Bu bağlamda, öğrenciler için gerek kampüse varmadan gerekse kampüse vardıktan sonra danışabilecekleri iletişim kanallarının varlığı ve etkinliği ön plana çıkmaktadır. Özellikle de, yabancı uyruklu öğrencilerin dil farklılıklarından dolayı yaşayabilecekleri iletişim güçlüklerini göz önünde bulundurarak, personelin onlara karşı daha özenli olması gerekmektedir. Çünkü bizim için normal olan konuşma ve davranış kalıpları, farklı bir kültürden gelen öğrenciler için anlaşılması güç olabileceği gibi incitici de olabilir. Bu noktada, yabancı öğrencilerle iletişim konusunda, öğrencilerle iletişim becerileri yüksek olan personelin görevlendirilmesi büyük ölçüde iyileştirmeyi sağlayacaktır. Böylelikle, yine öğrencilerin yaşayabilecekleri olumsuz tecrübeler azaltılmış olacak ve oluşabilecek olumsuz algılar da önlenmiş olacaktir.

- Son olarak, "yabancı uyruklu öğrenci" tanımlaması yerine "uluslararası öğrenciler" veya daha kucaklayıcı başka bir tanımlamanın geliştirilmesi, öğrencilerin kendilerini dışlanmış hissetmemesi ve üniversiteyi benimsemesi açısından önemli rol oynayacaktır.

İşbu iyileştirmelerin yapılması durumunda, yabancı uyruklu öğrencilerdeki Türkiye imajı değerinin daha da artacağı düşünülmektedir. Aslında, ülkemize gelen yabancı uyruklu öğrencilere gerekli imkânlar sunulmaktadır. Ancak, bu imkânlar sunulurken uygulanan usule ilişkin yapılacak bir kısım değişiklikler, yabancı uyruklu öğrencilerdeki Türkiye imaj değerinin doğru yönetilmesine yardımcı olacaktır. Böylelikle, sunulan imkânların karşılığının daha verimli bir şekilde alınmasını da mümkün kılacaktır. Bu bağlamda, genel olarak diğer eğitim kurumlarının da yapacağ1 benzer iyileştirmeler ile yabancı uyruklu öğrenciler sektöründen daha etkin bir şekilde istifade edilmesine katkı sağlanacaktır. Nihayetinde, yabancı uyruklu öğrencilerin, özelde üniversitemizin genelde ise ülkemizin dünyadaki imaj değerini artırabilecek önemli küresel elçiler olduğu unutulmamalıdır. 


\section{Kaynakça}

Akyürek, S. ve Bilgiç, S. (2012). Ermenistan'da Türkiye ve Türk Alg1sı. BILGESAM Raporu, Ankara.

Allport, G. W. (1979). The Nature of Prejudice. New York: Perseus Books.

Anholt, S. (2011). Beyond the Nation Brand: The Role of Image and Identity in International Relations. A. Pike içinde, Brands and Branding Geographies (s.s. 289). Cheltenham: Edward Elgar.

Annaberdiev D. (2006). Türkiye‘de Eğitim Gören Türk Cumhuriyetleri ve Türk Üniversite Öğrencilerinin Psikolojik Yardım Arama Tutumları, Psikolojik İhtiyaçları ve Psikolojik Uyumlarının Bazı Değişkenler Açısından İncelenmesi. Yayınlanmamış Yüksek lisans tezi, Ege Üniversitesi: İzmir.

Bayram, N. (2010). Yapısal Eşitlik Modellemesine Giriş: Amos Uygulamaları. Bursa: Ezgi kitapevi.

Bozkuş, Y. D. Ve Arı E. B. (2017). Güney Kafkasya Kökenli Öğrencilerin Türkiye'ye Gelmeden Önceki ve Geldikten Sonraki Türkiye Algılarının Değişimi. İstanbul: Bostanc1 Kırtasiye \& Matbaacllik.

Büyüköztürk, Ş. (2002). Faktör Analizi: Temel Kavramlar ve Ölçek Geliştirmede Kullanımı. Kuram Ve Uygulamada Eğitim Yönetimi, 32(32), 470-483.

Canadian Bureau for International Education. (2020). International Students in Canada. https:/ / cbie.ca/infographic/.

Coşkunserçe O. ve Erişti S. D. B. (2017). Uluslararası Öğrencilerin Kültürel Uyum Sürecine Yönelik Tasarım Tabanlı Araştırma Yaklaşımına Dayalı Çevrimiçi Oryantasyon Uygulamasının Geliştirilmesi. Eğitim Teknolojisi Kuram ve Uygulama, 7 (1), 83104.

Demirhan, K. (2017). Ulusal Alanyazında Uluslararası Öğrenciler ve Uluslararası Öğrencileri Siyasal Açıdan Düşünmek. Uluslararası Yönetim İktisat ve İşletme Dergisi, 13(5), 547-562.

Ghazarian, P. G. (2016). Country Image and the Study Abroad Destination Choice of Students from Mainland China. Journal of International Students, 6(3), 700-711. 
Göver, İ. H. ve Yavuzer, H. (2015). Kayseri'de Öğrenim Gören Yabancı Uyruklu Öğrencilerin Kayseri, Türkiye Ve İslam Alg1s1. Electronic Turkish Studies, 10(2), 1025-1050.

Güçlü, N. (1996). Yabancı Öğrencilerin Uyum Problemleri. Hacettepe Üniversitesi Eğitim Fakültesi Dergisi, 12(12), 101-110.

Gültekin, B. (2013). Türkiye'nin Uluslararası İmajında Yükselen Değerler ve Eğilimler. Selçuk İletişim, 4 (1), 126-140.

Kalaycı Ş. (2014). SPSS Uygulamalı Çok Değişkenli İstatistik Teknikleri. Ankara: Asil Yayıncılık.

Karabayev, B. ve Tutkun, Ö. F. (2001). Türk Cumhuriyetlerinden Gelen Öğrencilerin Türkiye Cumhuriyeti Vatandaşlarına Karşı Taşıdıkları Kalıp Yargılar. Bilig Dergisi, 18, 1-25.

Köylü M. (2001). O.M.Ü. İlahiyat Fakültesine Devam Eden Yabanc1 Uyruklu Öğrencilerin Fakülte Hakkındaki Düşünce, Sorun ve Beklentileri. Ondokuz Mayıs Üniversitesi İlahiyat Fakültesi Dergisi, Vol.12, 131-153.

Levent, F. ve Karaevli, Ö. (2013). Uluslararası Öğrencilerin Eğitimine Yönelik Politikalar ve Türkiye için Öneriler. Marmara Üniversitesi Atatürk Eğitim Fakültesi Eğitim Bilimleri Dergisi, 38(38), 97-118.

Miller, N. (2002). Personalization and the Promise of Contact Theory. Journal of Social Issues, 58(2), 387-410.

OECD (2020). International Student Mobility (indicator), https: / / doi.org/10.1787 / 4bcf6fc3-en.

OECD (2020). Number of Students (indicator). doi: 10.1787/ efa0dd43-en.

Paksoy H.M., Paksoy S. ve Özçalıcı M. (2012). Türkiye'de Yüksek Öğrenim Gören Yabancı Uyruklu Öğrencilerin Sosyal Sorunları: GAP Bölgesi Üniversiteleri Örneği. Kahramanmaraş Sütçü İmam Üniversitesi İktisadi ve İdari Bilimler Fakültesi Dergisi, 2(2), 85-94.

Pettigrew, T. F. (1998). Intergroup Contact Theory. Annual Review of Psychology, 49, 65-85.

Pettigrew, T. F. ve Tropp, L. R. (2005). Allport's Intergroup Contact 
Hypothesis: Its History and Influence. On the Nature of Prejudice: Fifty Years after Allport, 262-277.

Saran, M. ve Karpat, I. (2002). Türkiye'nin İmajı ve Marka Değerinin Arttırılmasında İletişim Çabaları. KalDer Dergisi, 141, 46-50.

SEVIS by the Numbers. (2018) Check Out the Latest SEVIS by the Numbers Report. US Department Homeland Security: Study in the States. https://studyinthestates.dhs.gov/2018/05/ check-out-the-latest-sevis-by-the-numbers-report.

Study in UK. (2020). International Student Statistics in UK 2020. https: / / www.studying-in-uk.org / international-studentstatistics-in-uk/.

Ş. Bahattin ve Bakır, S. (2016). Uluslararası Öğrenci Hareketliliği ve Atatürk Üniversitesinin Uluslararasılaşma Süreci. A. Ü. Türkiyat Araştırmaları Enstitüsü Dergisi, 55, 509-542.

T.C. Kalkınma Bakanlığı, Kalkınma Araştırmaları Merkezi. (2015). Yükseköğretimin Uluslararasılaşması Çerçevesinde Türk Üniversitelerinin Uluslararası Öğrenciler için Çekim Merkezi Haline Getirilmesi (Yayın No: 2936). Erişim Adresi: http:// www.sbb.gov.tr/wp-content/uploads/2018/11/Yuksekogretimin_ Uluslararai\% C4\%B1lasmasi_Cercevesinde_Turk_Universitelerinin_Uluslararasi_Ogrenciler_Icin_Cekim_Merkezi_Haline_Getirilmesi_Arastirma_Projesi_Raporu.pdf.

UNESCO, (2009). Global Education Digest 2009: Comparing Education Statistics across the World. Montreal: UNESCO Institute for Statistics.

UNESCO, (2009). Education: Outbound Internationally Mobile Students by Host Region. http: / / data.uis.unesco.org/Index. aspx?queryid=172.

Yıldıran C., Özkan D. ve Büyükyilmaz, O. (2016). Yabancı Uyruklu Lisans Öğrencilerinin Durum Analizi: Karabük Üniversitesi. Uluslararası Bilimsel Araştırma Dergisi, 1(1), 21-34. 